\title{
The Social, Economics, and Finance Analysis on Profit and Loss Sharing of Islamic Partnership (Case Study of Tobacco Bussiness in Jember Regency, Indonesia)
}

\author{
Novi Puspitasari ${ }^{1}$, Hari Sukarno ${ }^{2}$, Hikmah Wardatul Hasanah ${ }^{3}$ \\ ${ }^{1}$ Faculty of Economic and Business, Universitas Jember, Indonesia \\ ${ }^{2}$ Faculty of Economic and Business, Universitas Jember, Indonesia \\ ${ }^{3}$ Faculty of Economic and Business, Universitas Jember, Indonesia
}

\begin{tabular}{l}
\hline \multicolumn{1}{c}{ ARTICLE INFO } \\
\hline Article history: \\
Received June 8, 2021 \\
Revised August 16, 2021 \\
Accepted September 27, 2021 \\
Available online October 1, 2021
\end{tabular}

\section{Keywords:}

mukhabarah, muzara'ah, profit sharing

Paper type: Research paper

Please cite this article [Turabian of style 8th edition]: Puspitasari, Novi, Sukarno, Hari, AND Hasanah, Hikmah. " The Social, Economics, And Finance Analysis On Profit And Loss Sharing Of Islamic Partnership (Case Study of Tobacco Bussiness in Jember Regency, Indonesia)" IQTISHODUNA: Jurnal Ekonomi Islam [Online], Volume 10 Number 2 (1 October 2021)

*Corresponding author e-mail: *novipuspitasari@unej.ac.id

\begin{tabular}{l} 
ABSTRACT \\
\hline The purpose of this study are: (1) to investigate the \\
implementation of partnerships in the VOK tobacco \\
business in an Islamic perspective, whether include \\
mukhabarah, muzara'ah, or musagah contract; (2) to \\
explore the partnership implementation of VOK \\
tobacco business on social, economic, and finance. \\
This study use the snowball method with in depth \\
interview. This research captured that there are two \\
contracts of Islamic partnership on tobacco \\
business, namely mukhabarah and muzara'ah. The \\
social impact is the availability of jobs for people \\
who do not own land/rice fields, thus helping the \\
government to reduce unemployment and create \\
close kinship in the community. The manifestation \\
of the economic impact is that people who do not \\
own land can still earn income for live. This study \\
shows that there is a difference formula in \\
calculating the profit sharing between the net farm \\
income (NFI) and local culture formula. The local \\
cultural formula does not use the real cost to count \\
the net profit which is considered injustice. It is \\
important to note that injustice is something that is \\
against Islamic belief. Profit-sharing ratio between \\
landowner and land tiller is $50 \%$ : $50 \%$ of net \\
income. \\
\hline \\
IQTisHoDuna with CCBY license. Copyright $\odot 2021$, the author(s) \\
\hline
\end{tabular}

\footnotetext{
Abstrak:

Tujuan dari penelitian ini adalah: (1) untuk mengetahui implementasi kemitraan bisnis tembakau VOK dalam perspektif Islam, apakah termasuk akad mukhabarah, muzara'ah, atau musaqah; (2) menjajaki implementasi kemitraan usaha tembakau VOK di bidang sosial, ekonomi, dan keuangan. Penelitian ini menggunakan metode snowball dengan wawancara mendalam. Penelitian ini menangkap bahwa penerapan kemitraan syariah dalam bisnis tembakau menganut dua kontrak yaitu mukhabarah dan muzara'ah. Dampak sosial penerapan kemitraan Syariah adalah tersedianya lapangan pekerjaan bagi masyarakat yang tidak memiliki tanah/sawah, sehingga membantu pemerintah untuk mengurangi
} 
pengangguran dan menciptakan kekerabatan yang erat di masyarakat. Sementara itu, wujud dari dampak ekonomi tersebut adalah masyarakat yang tidak memiliki tanah tetap dapat memperoleh penghasilan untuk hidup. Penelitian ini menunjukkan bahwa terdapat perbedaan formula dalam menghitung bagi hasil antara pendapatan bersih usaha tani (NFI) dan formula budaya lokal. Rumusan budaya lokal tidak menggunakan biaya riil untuk menghitung laba bersih yang memunculkan anggapan tidak adil dimana hal ini merupakan sesuatu yang bertentangan dengan keyakinan Islam. Rasio bagi hasil pada penerapan kemitraan syariah antara pemilik tanah dan penggarap tanah adalah 50\%:50\% dari laba bersih.

Kata kunci. Mukhabarah, Muzara'ah, bagi hasil

\section{INTRODUCTION}

The agricultural sector is vulnerable to capital adequacy. ${ }^{1}$ Farmers do not have enough access to get capital. Several research findings suggest that one of the main problems in the agricultural sector is the lack of capital. ${ }^{2}$ The access of capital has become a major focus for policy makers in the agricultural sector, especially in developing countries ${ }^{34} .5$ add that limited capital access hampers productivity growth in the agricultural sector. Furthermore, 6

1 Suharno, "Revitalisasi Agrikultur Untuk Pertumbuhan Ekonomi: Perspektif Ekonomi Islam," Iqtishoduna: Jurnal Ekonomi Islam 8, no. 1 (2019): 141-155.

2 Ahmad Ajib Ridlwan, "Implementasi Akad Muzara'ah Pada Bank Syariah: Alternatif Akses Permodalan Sektor Pertanian," IQTISHODUNA: Jurnal Ekonomi Islam 5, no. 1 (2016): 34-48.

${ }^{3}$ A. A. Ammani, "An Investigation into the Relationship between Agricultural Production and Formal Credit Supply in Nigeria," International Journal of Agriculture and Forestry 2, no. 1 (2012): 46-52, https://doi.org/10.5923/j.ijaf.20120201.08.

4 C. O. A. Ugwumba and J. T. Omojola, "Credit Access and Productivity Growth Among Subsistence Food Crop Farmers in Ikole Local Government Area of Ekiti State , Nigeria" 8, no. 4 (2013): 351-356.

${ }^{5}$ A. Ammani (2012)

6 Novi Puspitasari ${ }^{1}$, Sutan Emir Hidayat, and Farida Kusmawati, "Journal of Islamic Financial Studies Murabaha as an Islamic state that in which one of the main problems in the agricultural sector is the lack of capital for the agricultural business. One way to overcome this problem is to make a partnership between land owners and land workers. Partnership is one of the Islamic models in the economic transaction. ${ }^{7}$ Islam has taught partnership in the agricultural sector in the form of mukhabarah, muzara'ah and musaqah contracts. These contracts use profit and loss sharing (PLS) system. ${ }^{8}$ state that PLS is prescribed as a cure for the ills of the debt-based finance and an opportunity for entrepreneurs to share, rather than to bear the risk of starting new businesses and/or expanding the existing ones. ${ }^{9}$ also strongly argue that if an Islamic financial instrument can take the

Financial Instrument for Agriculture," J. Islam. Fin. Stud 5, no. 1 (2019).

7 AM Hafidz Mashum and Marlina Marlina, "Nusantara Syariah Economy (Construction of Economic Cooperation between The Indonesian Muslim Community)," Iqtishoduna: Jurnal Ekonomi Islam 9, no. 2 (2020): 197-224.

8 R. N. Kayed, "The Entrepreneurial Role of Profit-and-Loss Sharing Modes of Finance: Theory and Practice," International Journal of Islamic and Middle Eastern Finance and Management 5, no. (2012)

203-228.

https://doi.org/10.1108/17538391211255205.

${ }^{9}$ R. N. Kayed, 2012. 
economy to new heights, that instrument must be based on the values of PLS contracts. ${ }^{10}$ analyze the problems that occur in the agricultural sector in Zanzibar, especially in the case of the glove industry. This study proposes the Waqf-Muzara'ah supply chain model. It is believed that the model will improve the welfare of small farmers and help them access financing and funding. It also increases their income through improved agricultural skills and good market relations and integration between companies. ${ }^{11}$ develop the muzara'ah supply chain model for the purpose of increasing agricultural finance and productivity in Nigeria.

12 discussed Mukhabarah as an Islamic financing model in cattle breeding companies. This financing pattern is very accommodative to the local culture of rural communities. The research

10 Issa Salim Moh'd, Mustafa Omar Mohammed, and Buerhan Saiti, "The Problems Facing Agricultural Sector in Zanzibar and the Prospects of WaqfMuzar'ah-Supply Chain Model: The Case of Clove Industry," Humanomics 33, no. 2 (2017): 189-210

https://doi.org/10.1108/H-02-2017-0033.

11 Nafiu Olaniyi Oladokun, Moussa Larbani, and Mustafa Omar Mohammed, "The Problems Facing the Agricultural Sector in Nigeria and the Prospect of Muzara'ah and Supply Chain Model," Humanomics 31, no. 1 (2015): 18-36.

12 A. Asnawi, A. A. Amrawaty, and N. Nirwana, "Mukhabarah as Sharia Financing Model in Beef Cattle Farm Entrepise," IOP Conference Series: Earth and Environmental Science 119, no. 1 (2018). discussing musaqah was conducted by ${ }^{13}$ This research recommends that the government systematically forms a Sustainable Food Agriculture Area (SFAA) on stateowned lands and establish institutions to manage the SFAA at the central and regional levels. ${ }^{14}$ also finds that the farmers in Aceh, Indonesia, apply musaqah on their plantations. The results of this research include: (1) the legal basis of musaqah is concentrated on the practice of the Prophet Muhammad, in agriculture on the land of khaibar with a Jew; (2) it is justified in combining musaqah with muzara'ah; (3) the people of Aceh are often familiar with musaqah in mawah traditions, whose practices include; gardens, rice fields and livestock; (4) Musaqah practices in the people of Aceh, especially in North Aceh, are in accordance with the concepts of Hadith and Islamic economic development.

Meanwhile, partnership activities have a social and economic impact on the perpetrators. ${ }^{15}$ states

13 Ujang Maman, Kusmana, and Dudi Kuspiandi, "' AL -MUSAQAH ' AND SHARIA AGRIBUSINESS SYSTEM: An Alternative Way to Meet Staple Food SelfSufficiency in Contemporary Indonesia. Hunafa: Jurnal Studia Islamik Vol. 14, Number 2, December 2017: 189-231.

14 Alimuddin, "Praktek Musaqah Dalam Masyarakat Aceh Utara (Suatu Analisis Perspektif Hadits)," AL-Mabhats: Jurnal Penelitian Sosial Agama 2, no. 1 (2017): 1-19.

${ }^{15}$ Krismon Tri Damayanti, "Perjanjian Bagi Hasil Dalam Kerjasama Pengelolaan Sawah Di Desa Sungai Rasau Dalam Perspektif Hukum Ekonomi Syariah," Jurnal 
that the cooperation agreement made even though it is done verbally can foster a good social spirit among the people of Sungai Rasau Village. The research conducted $^{16}$ explains that the implementation of the profit sharing system in Gorontalo District has a positive impact on smallholders to raise their economic level. Meanwhile, 17 also explained that the profit sharing system using the mawah method is a mutually beneficial way and is considered more dignified than the pawning or lease method, besides that the application of the mawah system also reduces the poverty rate in Aceh. ${ }^{18}$

The elaboration of the previous studies gives information that the system of partnership using the muzara'ah, mukhabarah and musaqah contracts has been widely applied in various regions and abroad in various types of farming, even in the animal husbandry sector. Previous researchers also

Intelektualita: Keislaman, Sosial dan Sains 8, no. 1 (2019): 1-10.

16 Rizal Darwis, "SISTEM BAGI HASIL PERTANIAN PADA MASYARAKAT PETANI PENGGARAP DI KABUPATEN GORONTALO PERSPEKTIF HUKUM EKONOMI ISLAM," Al-Mizan 12, no. 1 (2016): 1-25.

17 Nelly et al., "The Revenue Sharing of Agricultural Sector of Rice Through 'Mawah' System (Research in Kota Baro Aceh Besar)," Journal of Asian Scientific Research 8, no. 1 (2018): 13-20.

18 M. Mukhtasar \& A.Syahputra, "Optimizing The Mawah Concept for The Economy of The Aceh Community," Iqtishoduna: Jurnal Ekonomi Islam 9, no. 2 (2020): 167-180. discuss the system of partnership in the agricultural sector from various perspectives. However, the empirical studies have not yet elaborated the analysis of profit and loss sharing (PLS) technique in each contract. Some of these empirical studies have not shown research conducted in tobacco business. An initial survey by researchers showed the existence of a partnership contract in the management of the VOK tobacco business in Sumber Jeruk village, Kalisat sub district, Jember Regency, East Java, Indonesia.

Jember has a dominant role in producing tobacco in East Java, Indonesia ${ }^{19}$ Jember is proven to have several types of tobacco in several districts with a fairly large harvest area. The Voor Oogst Kasturi (VOK) tobacco is the most widely produced type of tobacco in Jember, Indonesia. VOK tobacco was produced in some areas in Jember. The three highest subdistricts producing VOK tobacco in 2019 were Kalisat, Pakusari, and Sukowono sub district. The VOK tobacco is a type of tobacco plant which is widely grown in Kalisat sub-district, Jember. In 2018, Kalisat Sub-district contributed 3,525 quintals to the production of VOK tobacco in Jember. This is the

19 Oryza Ardhiarisca, Merry Muspita, and Tanti Kustiasari, "ANALISIS FAKTOR INTERNAL DAN EKSTERNAL YANG MEMPENGARUHI PENGEMBANGAN AGRIBISNIS TEMBAKAU DI KABUPATEN JEMBER," Ilmiah Inovasi 15, no. 3 (2015): 64-70. 
highest production compared to other sub-districts. The VOK tobaccos in this sub-district are spread with a total harvest area of 2,350 hectares.

The aims of this study are (1) to investigate the partnership contract applied in the VOK tobacco business from an Islamic perspective, whether it uses muzara'ah, musaqah, or/and mukhabarah contracts; (2) to explore the effect of partnership implementation of VOK tobacco business on social and economic; (3) to explore the profit and loss sharing technique of mukhabarah and muzara'ah contracts in VOK tobacco business in Kalisat sub-district, Jember, East Java, Indonesia. This research contributes to the study of Islamic financial management especially related to the application of profit and loss sharing technique of muzara'ah, mukhabarah, and musaqah. This study also benefits entrepreneurs in agricultural sector, especially tobacco, where they can utilize the results of this research in their businesses. In addition, the government can disseminate the results of this study to agricultural business stakeholders to increase agricultural productivity in their working areas.

\section{Literature Review}

The term muzara'ah is a cooperation agreement between two people, where the first party, namely the land owner, surrenders his land to the second party, namely the cultivator, to be processed as agricultural land and the results are divided between them with a consideration of half, or one third two thirds or less or more the amount of the ratio, according to the results of their agreement. In this definition, Syafi'iyah requires plant seeds to be issued by the land owner, if the seeds are issued by the cultivator, the term is not muzara'ah, but mukhabarah.

Mukhabarah is working (someone else's) land such as rice fields or fields in exchange for a portion of the results (one-half, onethird, or one-quarter). Meanwhile, the working costs and the seeds are borne by the people who do it. The emergence of the meaning of muzara'ah and mukhabarah with different ta'rifs is due to the existence of scholars who differentiate between the meaning of muzara'ah and mukhabarah, namely Imam Rafi'i based on the dhahir nash of Imam Syafi'I. ${ }^{20}$ According to the narration from Ibn Umar, the Messenger of Allāh had given Khaibar land to its inhabitants (at that time they were still Jews) to work on in exchange for the share in the fruits and plants. Ulama Syafi'iyah explain Mukhabarah

Musaqah is taken from Arabic al-saqa, meaning someone works to manage the date and grape trees, or other trees in order to bring benefits and get a certain share of the

\footnotetext{
20 A. Rio Makkulau Wahyu, "Sistem Penggarapan Lahan Pertanian Masyarakat:," Al-Azhar Journal of Islamic Economics 1, no. 1 (2019): 1-15.
} 
produces in return. Jurisprudence scholars (Fuqoha) interpet musaqah as a contract to surrender the garden (trees) to farmers to work on the condition that the fruits (the produces) are shared by both owner and farmer. Meanwhile, Malikiyah defines al-musaqah as something that grows. According to Syafi'iyah, almusaqah is a contract where the people who have tamarind and grape give work to others in the forms of watering, maintaining, and guarding the trees, and workers get a certain portion of the fruits produced by these trees. Hasbi AshShiddieqi explains that al-musaqah is an agricultural company to obtain agricultural produces from trees.

\section{The Research Method}

This study applies qualitative method. The case study approach is chosen to dig deeper into the practice of profit and loss sharing technique applied in tobacco business. Researchers chose Jember Regency, East Java, Indonesia as the research location based on the existence of Jember as the largest tobacco producer in East Java. Meanwhile, the choice of Kalisat sub-district is due to the type of VOK tobacco that is mostly produced in the sub-district. Also, it is supported by the existence of a partnership practice in the management of the tobacco business in the sub-district.

This study uses snowball sampling technique in selecting the respondents. Snowball sampling is a network sampling design that preserves the information of the network structure. It is an iterative procedure of collecting vertices' information that is linked with vertices collected in the previous iteration. The snowball sampling is a cost-efficient method for collecting samples. Researchers can quickly obtain large amount of data by collecting information from the vertices linked with the samples in the previous iteration. ${ }^{21}$

In the early stages of the snowball technique, researchers asked their colleagues who reside in Kalisat sub-district to refer a farmer who participated in the partnership of managing the tobacco business. Mr. M. Daris Yansan is the name of the farmer referenced by the researchers' colleagues. Mr. M. Daris Yansan is as the first respondent in this study. Furthermore, researchers met $\mathrm{Mr}$. M. Daris Yansan to conduct an interview. He is the owner of the land. He was working with Mr. Da. He stated that he had a friend, Mrs. Watin Jumari, who also undertakes a partnership contract in tobacco management. Based on Mr. M. Daris Yansan's information, the researcher made Mr. Da and Mrs. Watin Jumari as the next respondents for this study.

Data were collected by depth interview. This study needed about two months to get all the data,

${ }^{21}$ Julian TszKin Chan, "Snowball Sampling and Sample Selection in a Social Network" $42 \quad$ (2020): 61-80 https://doi.org/10.1108/s0731905320200000042008. 
beginning from initial survey and observation to the completion of conducting interviews with respondents. Interviews with respondents required scheduling to match the respondent's willingness to conduct interviews. Researchers interviewed six (6) respondents, consisting of 3 land owners and 3 land tillers. The landowners are $\mathrm{Mr}$. M. Daris Yansan (42 years old), Mrs. Watin Jumari (68 years old), and Mrs. Sri Redjeki's (60 years old). The land tillers are Mr. Misnadi or Mr. Da (44 years old), Mr. Tono (37 years old), and Mr. Sunardi (49 years old). Researcher needed about 45 minutes to one hour to make a deep interview for each respondent.

This paper made comparison formula between local culture and Net Farm Income (NFI) formula to analyse the profit and loss sharing. Local culture formula is the calculation of profit-sharing that had been done by farmers continuously. Meanwhile, the NFI formula uses the following formula. NFI=Production Value -Total Cost.

The validity of the data in this study used theoretical triangulation techniques by matching the findings in the field with related theories. This research data was declared valid by confirming the field findings which were in line with the muzara'ah and mukhabarah contract theories.

This research was conducted in 2 stages. The first stage was a survey to the location and found an example of partnership in the management of the VOK tobacco business. The second stage is an exploration of the partnership practice by conducting interviews with related parties. The focus of exploratory studies is two (2), namely:

a) the suitability of partnership practices from an Islamic perspective by relating the practices to the mukhabarah, muzara'ah, or/and mukhabarah contracts;

b) profit sharing practice on the contract. Furthermore, the exploration results will be analyzed.

\section{RESULT AND DISCUSSION}

This section consists of several sub-sections. The first subsection describes the implementation of partnership. The second sub-section discusses the mukhabarah and muzara'ah contract underlying the partnership. The third sub-section discusses the profit and loss sharing of mukhabarah and muzara'ah. The descriptions of them are presented in sequence.

\section{The Partnership Implementation on Voor Oogst Kasturi Tobacco Business}

The partnership of the tobacco business has been carried out by farmers since long time in the Sub-district of Kalisat, Jember Regency, East Java, Indonesia. This is known from the results of interviews with respondents who stated that the partnership had begun in 1995. However, the partnership system is still very traditional without a written agreement. It is acceptable because, 
in general, the farmers already know and trust each other and have become a local culture.

In a partnership system, both parties receive the income by sharing profit of the business. It is also applied in the VOK tobacco business in Kalisat Sub-district, Jember Regency. Land owners and land tillers share profit of the tobacco business. The partnership is initiated by the land owner surrendering his land to be managed by land tiller. Land owner does not interfere in the business management. The land owner will be entitled to a share in the net harvest of tobacco. The net yield of a harvest is calculated by halving the proceeds from the sale of tobacco after deducting the costs of cultivation.

Mean while, Mr. Qois as the land owner revealed that all proceeds from the sale of tobacco were deducted by the costs incurred by $\mathrm{Mr}$. Da as the land tiller. Mr. Qois's statement can be an indication that the land tiller was the party who provided financing in the tobacco partnership. The capital expended by the land tiller included the costs of cultivation ranging from land preparation, procurement of seeds, fertilizer, irrigation, other treatments to the harvest, and the process of drying tobacco. This is different from the statement of Mrs. Sri Redjeki who is also the land owner. She revealed that she provided financing in her partnership. Mrs. Sri Redjeki's statement was strengthened by Mr.
Sunardi as a land tiller that he did not incur any costs in managing the tobacco business.

Another important information obtained from the respondents is that, the pattern of profit-sharing ratio in the tobacco business partnership system is 50\%:50\%. Land owner and land tiller would get each $50 \%$ of the proceeds from the sale of tobacco minus related costs. In other words, after the tobacco was sold, the land tiller deducted the sale proceeds with all related costs incurred. The net profit would be divided by a ratio of $1: 1$.

Islamic finance introduces two types of schemes in generating profits, namely profit and loss sharing (PLS) and non-profit and loss sharing (non-PLS). Profit and loss sharing (PLS) contract is a business agreement between two or more parties where all parties share their resources and the return is based on a predetermined ratio. Meanwhile, non-PLS contracts can generate profits through margins on sale and fee-based services. ${ }^{22} 23$

22 Bayu Arie Fianto, Christopher Gan, and Baiding $\mathrm{Hu}$, "Financing from Islamic Microfinance Institutions: Evidence from Indonesia," Agricultural Finance Review 79, no. 5 (2019): $633-645$ https://doi.org/10.1108/AFR-10-2018-0091.

23 Adil Elfakir, M. Tkiouat, R. Fairchild, R., \& A. Pakgohar, Can Real Options Reduce Moral Hazards in Profit and Loss Sharing Contracts ?: A Behavioural Approach Using Game Theory and Agent Based Simulation. Journal of Islamic Business and Management (JIBM), 10, no. 02 (2020): 284302 
explain that PLS contracts do not guarantee return on investments making them different from fixed income securities. The losses, however, must be shared with respect to each participant percentage share in the partnership capital. Profit sharing in this study has the same meaning as the PLS scheme as understood above.

Profit sharing is the activity of dividing the net profit of a business/project to parties who have contributed to the ongoing partnership in accordance with the proportion (nisbah) agreed. Profit sharing really depends on the profits of the business being run. If the business loses, the lossing will be borne together.

The implementation of partnership between land owners and land tillers has been described and analyzed in the previous paragraphs. Based on the review of the real implementation in the field, it provides the following information:

1. Partnership agreement is only made verbally without a written agreement. It becomes a tradition or local culture of tobacco farmers there.

2. There are two schemes related to financing on tobacco business. First, the land owners surrender their land to be managed and do not interfere in the cultivation of tobacco land, also does not give any financing. Second, land

https://doi.org/10.26501/jibm/2020.1002001. owners surrender the land and provide financing needs.

3. There are two types of of land tiller. First, land tiller who only manages the land without providing any financing at all; Second, the land tiller who manages the land and provides all the financing needs for tobacco cultivation including seeds, fertilizer, irrigation, tractor rental, and pays farm laborers on the land.

4. There is a profit sharing in the partnership of tobacco business with the proportion (nisbah) of 50\%: $50 \%$

\section{Mukhabarah and Muzara'ah Contract Underlying Voor Oogst Kasturi's Tobacco Business Partnership}

This paper informs that the tobacco business partnership system in Sumber Jeruk village, Kalisat Subdistrict is a system that has been carried out by tobacco farmers there since long time. This is a hereditary activity that has become a tradition in the tobacco farming. Based on Islamic perspective, a partnership system is highly recommended for running a business. Islam teaches Muslims to engage in economic activity. ${ }^{24}$ state that partnership contains a fair value and does not

24 Novi Puspitasari, Selvi Rias Bela, and Susanti Prasetyaningtyas, “Muzara'ah Pada Usaha Pertanian Padi: Analisis Nilai-Nilai Islami Dan Keuangan (Studi Di Kecamatan Bangsalsari Kabupaten Jember)," Bisma :Jurnal Bisnis dan Manajemen 14, no. 1 (2020): 71-80. 
oppose other parties in doing business.

Overall, the partnership implementation of VOK tobacco business in Sumber Jeruk village, Kalisat Sub-district, Jember Regency is in harmony with the muzara'ah and mukhabarah contracts. According to Hanabilah, muzara'ah is a contract where the owner of the land surrenders his land to be planted by the laborers and the owner also provides seeds. In line with the explanation of Ibrahim alBanjuri who stated muzara'ah is a contract between land owner and worker where worker manages a land with the payment of a part of what is generated from it and capital is provided by the land owner. The opinion of Hanabilah and Ibrahim al Banjuri that states "those who work are given seeds" and "capital from landowners" shows conformity with the practice of VOK tobacco business partnership in Sumber Jeruk village, Kalisat Subdistrict. The respondent, Mrs. Sri Redjeki, explained that she, as the land owner, provides all the capital and needs in tobacco cultivation. This is reinforced by the statement of Mr. Sunardi as her partner that he did not incur any costs in cultivating tobacco.

Meanwhile, Priyadi and Shidiqie (2015) explain that the mukhabarah agreement is a contract of partnership between the land owner and the land tiller, where the land owner surrenders the land to the land tiller to be managed. Then, the business outcomes are divided between the land owner and the land tiller in accordance with the agreed ratio. This explanation is in accordance with the practice of partnership in VOK tobacco business carried out by farmers in the Sumberjeruk village, Kalisat Sub-district, Jember regency. The land owner stated that they did not incur any costs and the land tiller who financed the needs on the land such as buying seeds, fertilizers, plowing the fields, irrigating the fields, and buying pesticides. This study concluded that muzara'ah and mukhabarah contracts are applied in the partnership of $\mathrm{VOK}$ tobacco business in Kalisat Sub-district, Jember, East Java.

The Social and Economic Analysis of Mukhabarah and Muzara'ah Contracts in Voor Oogst Kasturi Tobacco Business

The practice of mukhabarah and muzara'ah contracts has significant social and economic impacts on farmers. The form of social impact is that farmers who do not own land can have a job by working on other farmers' land. This job ownership has greatly helped the government to reduce unemployment so that the poverty of the people in Sumberjeruk village has also decreased. Another social impact is the creation of close kinship within the village community of Sumberjeruk. Farmers who do not own land will find it helpful in terms of earning a living. Meanwhile, farmers who own land but do not have the time 
or skills to cultivate the land can still enjoy the results of land management. This condition creates a relationship of mutual need which benefits both parties and creates a sense of brotherhood in society.

The manifestation of the economic impact of the practice of cooperation between mukhabarah and muzara'ah is that landless communities can earn income for the survival of tobacco farmers. This income is a source of income for tobacco farmers which is used to make ends meet, including for consumption, for children's school fees, fees for doctors when they are sick, and part of it is saved for the future.

There is a positive socioeconomic relationship to muzara'ah and mukhabarah. ${ }^{25}$ The hadith of the Prophet narrated by Bukhari and Muslim from Ibn Abbas r.a states as follows:

"Verily the Prophet. states, it is not forbidden to do zara'ah, he even ordered him to love some of the others, in that he said, whoever owns the land, then he should plant it or give benefits to his brother, if he does not want to, then he can just retain the land"

The hadith shows that the prophet Muhammad actually had a

${ }^{25}$ R. Rasiam, "RELASI SOSIO-EKONOMI PETANI DENGAN PEMILIK LAHAN MELALUI MUKHABARAH MUZARA'AH KONSEP DAN DI DESA ARANG LIMBUNG KECAMATAN SUNGAI RAYA KABUPATEN KUBU RAYA," Al-Maslahah Jurnal Ilmu Syariah 12, no. 2 (2016): 425-446. very noble mission to create social relations in the form of an economy between the rich (landlords) and the poor (farmers). Pre-Islamic Arab life was very disorganized where the rich oppressed the weak in various ways. The presence of the prophet Muhammad (saw) acts as a catalyst (connector and liaison) between the two groups of rich and poor people to distribute wealth so as to realize equitable welfare.

\section{Profit and Loss Sharing Analysis of Mukhabarah and Muzara'ah Contracts in Voor Oogst Kasturi Tobacco Business}

This section discusses profit and loss sharing technique on mukhabarah and muza'raah contracts by comparing the practice of profitsharing calculation between local culture and the NFI formulas. This financial analysis begins with the calculation of profit sharing according to local culture by extracting information in the field. Then, the next discussion describes the calculation of profit sharing using the NFI formula. The first discussion is about financial management of the mukhabarah contract. The next is financial management of the muzara'ah contract.

\section{Profit and Loss Sharing Technique of Mukhabarah Contract}

Profit and loss sharing analysis of mukhabarah contract used interview data from Mrs. Watin which include the area, the cost required for one tobacco harvest, 
and the nominal sales of tobacco. She had a land area of $275 \mathrm{~m}^{2}$. Mr. Tono was the land tiller of Mrs. Watin's land. The calculation of profit sharing according to the custom carried out by farmers is the subtraction of IDR 1,000,000.00 from the sale proceeds of tobacco. Whatever the actual costs incurred by the land tiller, IDR 1,000,000.00 must be deducted from the sale proceeds of tobacco. The inference is derived from Mr. Tono's expression at the interview section. The statement is described as follows.

"If the actual cost is calculated, let say it costs that much, but I will only deduct the cost of IDR $1,000,000$, because if it is deducted everything, I cannot share the profit (or very little)".

Meanwhile, tobacco sales of Mrs. Watin amounted to IDR $8,000,000.00$. The agreed profitsharing ratio is $50 \%: 50 \%$. Therefore, the calculation of profit sharing is as follows:

$$
\begin{aligned}
\text { Gross Profit } & =\text { sales }- \text { IDR } 1,000,000 \\
& =8,000,000-1,000,000 \\
& =7,000,0000
\end{aligned}
$$

Profit sharing for land owner

$=50 \% \times$ IDR $7,000,000$

$=$ IDR 3,500,000

Profit sharing for land tiller

$=50 \% \times$ IDR $7,000,000$

$=$ IDR 3,500,000

The profit-sharing nominal based on local culture for each land owner and land tiller is IDR 3,500,000. This paper also calculates the profit sharing using the NFI formula. This formula requires the nominal of total costs, which is the total costs incurred by land tiller in planting tobacco for one harvest. The total costs of Mrs. Watin's land are listed in Table 3. These costs were incurred by Mr. Tono. The total cost according to $\mathrm{Mr}$. Tono is IDR $1,365,000.00$. The production value or equivalent to the sales value is IDR $8,000,000.00$ and the profitsharing ratio is $50 \%: 50 \%$. Therefore, the profit-sharing calculation is as follows:

NFI $=$ Value of production-total cost of farming

$=\operatorname{IDR} 8,000,000-$ IDR 1,365,000

$=$ IDR 6,635,000

Profit sharing for land owners

$=0,5 \times$ IDR $6,635,000=$ IDR

3,317,500

Profit sharing of tiller farmes

$=0,5 \times$ IDR $6,635,000=$ IDR $3,317,500$

The nominal amount of profit sharing for each party in NFI calculation is different from local culture formula. Calculation of profit sharing using the local culture has a greater nominal compared to the NFI formula. In fact, the calculation of profit sharing using the local culture formula is detrimental to the land tiller because the deductible cost is less than the actual expenditure.

\section{Profit and Loss Sharing on Muzara'ah Contract}

To get the profit-sharing nominal in the muzara'ah contract, the first step is to calculate income using the NFI formula. This study uses cooperation data between Sri Redjeki and Mr. Sunardi. She was 
the land owner, and Mr. Sunardi was the land tiller. Sunardi planted 2,500 seedlings in Sri Redjeki's land. The planting of 2,500 seedlings resulted in sales of IDR 5,800,000.00. The total costs of planting are IDR $1,750,000$. Details of cooperation data between Sri Redjeki and Mr. Sunardi are presented in Table 4. It shows that the calculation of profit sharing according to the NFI formula is as follows:

NFI = Production Value-Total Cost of

$$
\begin{aligned}
& \text { Farming } \\
= & 5,800,000-1,750,000 \\
= & 4,050,000
\end{aligned}
$$

Profit sharing for land owners

$=50 \% \times 4,050,000=2,025,000$

Profit sharing of land tiller

$=50 \% \times 4,050,000=2,025,000$

Based on NFI formula, we got the profit-sharing nominal for each party is IDR 2,025,000.00. However, the actual practice differs from the calculation based on the interview. Deduction nominal is not IDR 1,750,000.00, but IDR 1,300,000.00. This is indicated by the statement of Mr. Sunardi as follows:

"Yes, the total cost is IDR 1,750,000,

but I only deducted IDR 1,300,000 from net sales of IDR 5,800,000. So, the amount of profit before distribution is IDR 4,500,000"

Mr. Sunardi's statement shows that when the tobacco harvest arrived, the land tiller sold the tobacco. Although the real costs incurred by the land owner amounted to IDR $1,750,000.00$ but land tiller returned only IDR 1,300,000 to the land owner at the time of harvest. The difference of it is very possible because both parties did not record anything related to the costs incurred. In this condition, the land owner is actually losing money. However, the land owner has never asked and not concerned about it because both parties have trusted each other. Thus, this study conducted a second stage calculation using a local culture formula in order to show the difference in the results of the two calculation models. The calculation based on local culture is as follows.

Profit = Sales - IDR $1,300,000$

$=5,800,000-1,300,000$

$=4,500,0000$

Profit sharing for land owner

$=50 \% \times$ IDR $4,500,000$

$=$ IDR 2,225,000

Profit sharing for land tiller

$=50 \% \times$ IDR $4,500,000$

$=$ IDR 2,225,000

Calculations using the local culture formula derive the nominal profitsharing amount of IDR 2,225,000 for each party. IDR 225,000 is higher than the amount based on NFI formula.

There are differences in the amount of profit sharing between NFI formula and local culture. NFI formula uses real total costs. Meanwhile, local culture formula uses verbal agreement between the land owner and the land tiller for counting the net profit as income distributed. Actually, the practice of profit-sharing calculation based local culture in this community shows injustice on muamalah transaction. Injustice is something 
that is against Islamic belief. Allah obliges all people to always be fair in all dealings because fair deeds indicate submission to Allah SWT. Being fair to others is contained in the Al-Quran surah An-Nahl verse 90 which means:

"Verily, Allah commands (you) to be just and do good, to give to your relatives, and Allah forbids from vile acts, munkar and enmity. Allah teaches you so that you can take lessons".

${ }^{26}$ explain that the concept of 'fair' in Islamic teachings is all-embracing. A Muslim is his expected to be fair to God, fair to himself and his family members and fair to the society. Fairness in the Islamic context is not merely based on human reasoning and interpretation but on what has been revealed by God as well, as explained in the Qur'an, AlMa'idah, 5:8:

"O ye who believe! Stand out firmly for Allah [God], as witness to fair dealing, and let not the hatred of others to you make you swerve to wrong and depart from justice. Be just; that is next to piety; and fear Allah [God]. For Allah is well acquainted with all that ye do."

Justice is mentioned in the Holy Quran on numerous occasions 27.

26 A. Salihin, A. H Fatima, \& A. A. Ousama, "Analysis of the True and Fair View Concept: An Islamic Perspective," International Journal of Managerial and Financial Accounting 7, no. 1 (2015): 38-61, https://doi.org/10.1504/IJMFA.2015.06749 9 .

27 Absar Aftab Absar, " Restorative Justice in Islam with Special Reference to the
Historically, the concept of a just person has been integral to legal determinations in Islamic law, including an individual's qualification for giving court testimony. ${ }^{28}$ explain that justice is the goal of Islamic law, as it is the goal for Islamic society in general. In both the Quran and Hadith, justice requires the offender to take personal responsibility for his or her actions and in most of the cases compensate the harms and losses of the victim.

An unbalanced economic system will create unsecured desires, sharpen material passions, and instill envy and envy in humans. This makes humans selfish and disregarding morals. Justice is very important so that Allah makes fair as one of the attributes of Allah, it is found in the Qur'an Surah AlRahman verse 7 which means:

"And Allah has exalted the heavens and He put a balance (justice)"

Thus, the results of this study recommend competent parties like academics to teach and show the community on how to practice profit-sharing calculations that create justice for both parties which is based on NFI formula. It can be done through community service programs. The competent parties in this regard include academics who have competence in the field of Islamic finance.

Concept of Diyya ," Journal of Victimology and Victim Justice 3, no. 1 (2020): 38-56.

$28 \mathrm{ibid}$. 


\section{Concluding Remark}

This study aims to explore the practice of partnership in VOK tobacco in Sumber Jeruk village, Kalisat Sub-district, Jember Regency, Indonesia from an Islamic perspective. Based on the results of interviews and data analysis, it can be concluded that muzara'ah and mukhabarah contracts are applied in the partnership of $\mathrm{VOK}$ tobacco business. They are muamalah contracts for agricultural sector. Islam teaches to carry out partnership including in the field of agriculture where it has many advantages, including overcoming difficulties in accessing capital, fostering a sense of fairness and not to be dzalim (cruel).

The practice of partnership is grouped into types of mukhabarah contracts based on the fulfillment of seeds, fertilizer, and other costs that are the responsibility of the land tiller. Meanwhile the muzara'ah contract is identified by the actions of the landowner who is responsible for procuring seeds and fertilizers and financing the tobacco cultivation. The practice of cooperation use mukhabarah and muzara'ah contracts have social and economic impacts. The social impact is the availability of jobs for people who do not own land/rice fields, thus helping the government to reduce unemployment and create close kinship in the community of Sumberjeruk village, Kalisat subdistrict, Jember district. Meanwhile, the manifestation of the economic impact is that people who do not own land can still earn income for live. The study finds that the profitsharing ratio applied is 50\%:50\%. It also finds that there are differences in the calculation of profit sharing between NFI and local cultural formulas. The local cultural formula does not use the real cost to count the net profit which is considered injustice. It is important to note that injustice is something that is against Islamic teachings.

This research has implications for policy makers (in this case the government), academics, and farmers. First, it is time for the government to promote the cooperation scheme of mukhabarah and muzara'ah in the agricultural sector because it has had a good impact from the social and economic side of the community. The government conducts outreach to the community by providing a special stimulus for those who run the cooperation scheme, for example assistance with fertilizers, seeds, or equipment by showing a letter of cooperation between the farmer who owns the land and the land cultivator. Second, academics as competent parties who have Islamic finance educational background must teach about profit-sharing calculations using NFI formula. Third, the farmers should take notes of transactions so that each cost is recorded in details. It is to anticipate the difference between real costs and reported costs to the business partners. The perpetrators of partnership should use the actual costs in determining 
IQTISHODUNA: Jurnal Ekonomi Islam

Volume 10 Issue 2, October 2021

the amount of profit to be shared between land owners and land tillers. This is to create a true sense of justice among them. 


\section{REFERENCES}

A. Ammani, A. 2012. An Investigation into the Relationship between Agricultural Production and Formal Credit Supply in Nigeria. International Journal of Agriculture and Forestry, 2(1), 46-52. https:/ / doi.org/10.5923/j.ijaf.20120201.08

Absar, A. A. 2020. Restorative Justice in Islam with Special Reference to the Concept of Diyya . Journal of Victimology and Victim Justice, 3(1), 38-56. https:/ /doi.org/10.1177/2516606920927277

Alimuddin. 2017. Praktek Musaqah dalam Masyarakat Aceh Utara (Suatu Analisis Perspektif Hadits). AL-Mabhats: Jurnal Penelitian Sosial Agama, 2(1), 1-19.

Ardhiarisca, O., Muspita, M., \& Kustiasari, T. 2015. Analisis Faktor Internal dan Eksternal yang Mempengaruhi Pengembangan Agribisnis Tembakau di Kabupaten Jember. Ilmiah Inovasi, 15(3), 64-70.

Asnawi, A., Amrawaty, A. A., \& Nirwana, N. 2018. Mukhabarah as Sharia Financing Model in Beef Cattle Farm Entrepise. IOP Conference Series: Earth and Environmental Science, $\quad 119(1) . \quad$ https://doi.org/10.1088/1755$1315 / 119 / 1 / 012068$

Chan, J. T. 2020. Snowball Sampling and Sample Selection in a Social Network. 42, 61-80. https://doi.org/10.1108/s0731-905320200000042008

Damayanti, K. T. 2019. Perjanjian Bagi Hasil dalam Kerjasama Pengelolaan Sawah di Desa Sungai Rasau dalam Perspektif Hukum Ekonomi Syariah. Jurnal Intelektualita: Keislaman, Sosial Dan Sains, 8(1), 1-10. https://doi.org/10.19109/intelektualita.v8i1.4222

Darwis, R. 2016. Sistem Bagi hasil Pertanian pada Masyarakat Petani Penggarao di Kabupaten Gorontalo Perspektif Hukum Ekonomi. Al-Mizan, 12(1), 1-25.

ELFAKIR, A., TKIOUAT, M., Fairchild, R., \& Pakgohar, A. 2020. Can Real Options Reduce Moral Hazards in Profit and Loss Sharing Contracts ?: A Behavioural Approach Using Game Theory and Agent Based Simulation. Journal of Islamic Business and Management (JIBM), 10(02), 284-302. https://doi.org/10.26501/jibm/2020.1002-001

Fianto, B. A., Gan, C., \& Hu, B. 2019. Financing from Islamic microfinance institutions: evidence from Indonesia. Agricultural Finance Review, 79(5), 633-645. https://doi.org/10.1108/AFR-10-2018-0091

Kayed, R. N. 2012. The entrepreneurial role of profit-and-loss sharing modes of finance: theory and practice. International Journal of Islamic and Middle Eastern Finance and Management, Vol. 5, pp. 203-228. https://doi.org/10.1108/17538391211255205

Maman, ujang, kusmana, \& Kuspiandi, D. 2017. " AL -MUSAQA H" AND SHARIA AGRIBUSINESS SYSTEM: An Alternative Way to Meet Staple Food SelfSufficiency in Contemporary Indonesia. Hunafa: Jurnal Studia Islamik Vol. 14, Number 2, December 2017: 189-231

Mashum, AM Hafidz, and Marlina Marlina. 2020. "Nusantara Syariah Economy (Construction of Economic Cooperation between The Indonesian Muslim Community)." IQTISHODUNA: Jurnal Ekonomi Islam 9 (2): 197-224.

Moh'd, I. S., Omar Mohammed, M., \& Saiti, B. 2017. The problems facing agricultural sector in Zanzibar and the prospects of Waqf-Muzar'ah-supply chain model: 
The case of clove industry. Humanomics, 33(2), 189-210. https://doi.org/10.1108/H-02-2017-0033

Mukhtasar, M., \& Syahputra, A. 2020. “Optimizing The Mawah Concept for The Economy of The Aceh Community". IQTISHODUNA: Jurnal Ekonomi Islam, 9(2), 167-180.

Nelly, Rahmi, Nurhayati, \& Ibrahim, M. 2018. The Revenue Sharing of Agricultural Sector of Rice Through "Mawah" System (Research in Kota Baro - Aceh Besar). Journal of Asian Scientific Research, 8(1), 13-20. https://doi.org/10.18488/journal.2.2018.81.13.20

Oladokun, N. O., Larbani, M., \& Mohammed, M. O. 2015. The problems facing the agricultural sector in Nigeria and the prospect of muzara'ah and supply chain model. Humanomics, 31(1), 18-36. https://doi.org/10.1108/H-11-2012-0022

Puspitasari, N., Selvi Rias Bela, \& Prasetyaningtyas, S. 2020. Muzara'ah pada Usaha Pertanian Padi: Analisis Nilai-nilai Islami dan Keuangan (Studi di kecamatan Bangsalsari Kabupaten Jember). Bisma:Jurnal Bisnis Dan Manajemen, 14(1), 7180.

Puspitasari, N., Hidayat, S. E., \& Kusmawati, F. 2019. Journal of Islamic Financial Studies Murabaha as an Islamic Financial Instrument for Agriculture. J. Islam. Fin. Stud, 5(1). Retrieved from http://journals.uob.edu.bh

Rasiam, R. 2016. Relasi Sosio-Ekonomi Petani Dengan Pemilik Lahan Melalui Konsep Mukhabarah dan Muzara'ah di Desa Arang Limbung Kecamatan Sungai Raya Kabupaten Kubu Raya. Al-Maslahah Jurnal Ilmu Syariah, 12(2), 425-446.

Ridlwan, Ahmad Ajib. 2016. "Implementasi Akad Muzara'ah pada Bank Syariah: Alternatif Akses Permodalan Sektor Pertanian." IQTISHODUNA: Jurnal Ekonomi Islam 5 (1): 34-48.

Salihin, A., Fatima, A. H., \& Ousama, A. A. 2015. Analysis of the true and fair view concept: An Islamic perspective. International Journal of Managerial and Financial Accounting, 7(1), 38-61. https:// doi.org/10.1504/IJMFA.2015.067499

Suharno. 2019. "Revitalisasi Agrikultur untuk Pertumbuhan Ekonomi: Perspektif Ekonomi Islam." IQTISHODUNA: Jurnal Ekonomi Islam 8 (1): 141-155.

Ugwumba, C. O. A., \& Omojola, J. T. 2013. Credit Access and Productivity Growth Among Subsistence Food Crop Farmers in Ikole Local Government Area of Ekiti State, Nigeria. 8(4), 351-356.

Wahyu, A. R. M. 2019. Sistem Penggarapan Lahan Pertanian Masyarakat: Al-Azhar $\begin{array}{llll}\text { Journal of Islamic Economics, } & 1(1), & 1-15\end{array}$ 